\title{
Occupational Health and Safety Hazards and Risks in Nigerian Commercial Banks
}

\author{
Ajibawo O. A, Adesope O, Chinemerem P
}

\begin{abstract}
This study investigated the occupational health and safety hazards and risks among bank workers, using banks in Lagos State as a case study. A cross sectional survey method of research design was adopted for the study. Sample size of355 respondents were randomly selected from six commercial banks. The instruments for data collection werevalidated andquestionnairedesigned to a 5 Point Likert scale with a reliability coefficient of 0.84 .Data were analyzed using descriptive statistics of percentage, frequency distribution, mean and standard deviation. Results showed that the top most common hazards the workers encountered were stress with criterion mean of 3.18, workload with criterion mean of 2.97 , eyes strain with criterion mean of 2.68 , noise with criterion mean of 2.6366 and ergonomic strain with criterion mean of 2 . 44. The least common occupational health and safety hazards the bankers experience were poor body posture (criterion mean 2.23), poor ventilation (criterion mean - 2.26), poor housekeeping (criterion mean-2.21), sexual harassment (criterion mean-2.14), and workplace violence (criterion mean-2.12).
\end{abstract}

Index Terms - Occupational health and safety hazards, Risks, Stress, Workplace injuries, Nigerian banks.

\section{INTRODUCTION}

Report shows that approximately 2.2 million deaths are recorded each year due to work-related accidents or ill health, which is equivalent to the population of some small countries [1]. These deaths could have been prevented with effective safety procedures in place. Reports show that attention given to health and safety in the workplace is quite poor in developing nations; exposure to hazard is high, tasks are mostly performed manually, and the quality or standard of record keeping is poor [2]-[4]. The International Labor Organization (ILO) encourages development of reliable report on; causes of occupational accidents, how to eliminate or minimize these accidents and general OHS in work-place. Based on these reports, countries should initiate and develop suitable national programmes to minimize or eliminate accident occurrence in work-environment [1].

The report of [5] shows that over 2.31 million deaths of workers globally, is from accidents and diseases at work. This results to huge economic-loss, human suffering, and reduced productivity etcetera. It alsoassessed the cost-effect of this in

Ajibawo O. A, Centre for Occupational Health, Safety and Environment, University of Port Harcourt, Rivers State, Nigeria

Adesope, $\mathbf{O}$, Centre for Occupational Health, Safety and Environment, University of Port Harcourt, Rivers State, Nigeria

Chinemerem, P, Centre for Occupational Health, Safety and Environment, University of Port Harcourt, Rivers State, Nigeria workplaces at approximately 4\% of Gross-National-Product of each nation. This estimate is higher in developing nations where safety performance is low compared to already developed countries[6]. Employees have a responsibility, which is; to work safe with hazardous-materials, protect themselves, learn to identify and prevent hazards in workplaces. According to [7], work-related hazards include psychosocial, physical, mechanical, chemical and biological.

Different countries encounter different risks and these risks are peculiar to each sector. Hence, the call for national plans on OHS to curb the situation, which forms the framework of the ILO safety and health. From report, 350,000 fatal accidents, 264 million non-fatal accident occurred in 1998 worldwide. Furthermore, 160 million workers suffer from work-related diseases, resulting to absence of workers for some days in workplaces. This report varies across countries based on the nations OHS state [1].

Banking is in the service sector of the economy. The service sector consists of the "soft" parts of the economy and activities where people offer their knowledge and time to improve productivity, performance, potential, and sustainability, what is termed affective labor [8]. The basic characteristic of this sector is the production of services instead of end products. A bank is a financial institution and a financial intermediary that accepts deposits and channels those deposits into lending activities, either directly by loaning or indirectly through capital markets. Banks also enable customer payments via other payment methods such as Automated Clearing House (ACH), wire transfer and automated teller machine (ATM). It is a well-known fact that the banking sector has continued to be one of the largest employers of labour in Nigeria [9]. Before the latest reforms, the banking sector was the second highest employer of labour after government [10]. This means that Bankers constitute a reasonable amount of the Nigerian labour force. Nigerian Bankers work long hours, starting each day's job early in the morning and sometimes closing as late, as midnight; working from $12-15$ hours and more daily which may even extend to weekends. The nature of the bank work and the working environment can have negative impacts on the health of the banker [8]. Posture problems from sitting or standing too long in a static position, vision difficulties from gazing into a computer screen for prolonged periods of time, musculoskeletal disorders, unhealthy eating habits, stress problems resulting from overwork, mental health issues caused by job insecurity, harassment, abuse, bullying, friction etc. are just some of the health hazards and risks that can ensue as a result of working in a Nigerian bank. 


\section{Occupational Health and Safety Hazards and Risks in Nigerian Commercial Banks}

Given that there is no comprehensive and complete information based on occupational hazards and risks in Nigerian commercial banks, the purpose of this study was to identify the information gap on the hazards and risks experienced by bank workers in Lagos State. This study therefore aims to identify the occupational health and safety hazards and risks among bank workers in Lagos State, examine the perception of bank workers on occupational hazards and risks, and their perception on the management of occupational health and safety hazards and risks.

\section{RESEARCH METHODOLOGY}

\section{A. Research Design}

The study used a descriptive survey research design method. Descriptive survey research design method was considered appropriate as it is efficient, fast, accurate and less expensive method of extracting information from a population and has been used in similar studies carried out by [8], [11]- [13]. This study was carried out to assess the occupational hazards risks encountered in Nigerian commercial banks and how these hazards and accompanying risks are managed.

\section{B. Study Area}

The study area for this research is Lagos, the fifth largest economy in Africa, located in the south west region of Nigeria and circumscribed by Ogun state to the north and east, west by Republic of Benin and to the south, by the Atlantic Ocean. The choice of Lagos as the study area is premised on its commercial nature, advance urbanization, and vast population.

Lagos which lies on geographic coordinates of $635 \mathrm{~N}$ and 345 E spreads over 3,577 kilometers accommodates head offices of most banks in Nigeria, multinational organizations, embassies, and supermarkets and is also known to support new businesses and commerce, and has twenty local government areas, and a GDP of \$91 billion. All commercial banks except one have their headquarters in Lagos and several

branches operating across Lagos. They all have centralized operations driven by technology and have accessible branches.

\section{Study Population}

Twenty-three commercial banks are licensed to render financial services in Nigeria by the Central Banks of Nigeria, the regulator of banks in Nigeria. Workers in six banks namely United Bank of Africa, First Bank of Nigeria, Union Bank of Nigeria, Fidelity Bank Plc, First City Monumental Bank Plc and Providus Bank Limited were sampled.

Table 1 shows the population size of the workers in the selected commercial banks. The population consists of different categories of bank workers including Branch Manager, Branch Operation Manager, Relationship Manager, Operation Executives, Occupational Health and Safety Management System Coordinators and Customer Service Officers.
Table 1: Population of staff in the six selected commercial banks

\begin{tabular}{cclcc}
\hline SN & Tier & Name of Bank & Population & Percent \\
\hline 1 & 1 & First Bank & 800 & 25.26 \\
2 & 1 & UBA & 900 & 28.42 \\
3 & 1 & Union Bank & 780 & 24.63 \\
4 & 2 & Fidelity Bank & 382 & 12.06 \\
5 & 2 & FCMB & 180 & 5.68 \\
6 & 3 & Providus Bank & 125 & 3.95 \\
& & Total & $\mathbf{3 1 6 7}$ & $\mathbf{1 0 0}$ \\
\hline
\end{tabular}

\section{Sampling Technique}

The study used three sampling techniques namely disproportionate stratified random sampling, purposive sampling and simple random sampling techniques. $25 \%$ of the commercial banks in Nigeria were purposively selected for the study based on their brand value and visibility, spread, transactional volume, accessibility and willingness to participate in the study. The six banks thus selected were from all the three tiers of the commercial banks, another form of categorization of the commercial banks by rating firms including the Central Bank of Nigeria. In addition, disproportionate stratified random sampling technique was utilized at the discretion of the researcher on the population which had three distinct categories of commercial banks into Tier 1, Tier 2 and Tier 3 and based on history of corporate performance of the banks over the years, size of business, asset base, management competence, credit rating and brand value among others. The disproportionate population selected was in the ratio $3: 2: 1$.

Lastly, simple random sampling technique which gives room for equal chance of selecting bank workers was used for the selection of respondents in the study. The bank workers selected by simple random sampling technique provided information on the occupational health and safety hazards and risks in the bank.

\section{E. Data Collection}

Questionnaire was used as the main instrument for the collection of primary data for this study. A well-structured questionnaire modelled after the ISO 45001 occupational health and safety management system standard and similar to the instrument used by[13], [14] were randomly distributed to staff of the banks within the study area. 355 respondents participated in the study. The respondents were chosen from different areas of the banks and occupied roles vital to the banks operations.

\section{F. Data Analysis}

Data analysis was performed using SPSS software version 22. Data gathered were presented via tables and charts and analyzed using frequencies, mean, percentages and standard deviation. 


\section{RESULTS}

The demographic distribution of the respondents is shown in Figure 1. The figure shows that $57.7 \%$ of the respondents were female, while $42.3 \%$ of the respondents were male. A lot of the respondents were within the age range of $25-34$ years which accounted for $57.7 \%$ of the sample size. $32.1 \%$ of the respondents were within the age range of 35-44 years, while $3.4 \%$ of the respondents were within the age range of $45-54$ years and $6.8 \%$ of the respondents were within the age range of 18-24 years. No respondent was within the age range of 55 years and above in the population. However, majority of the respondents are bachelor degree holders, corresponding to $56.9 \%$ of the population, while $23.9 \%$ of the respondents hold NCE/HND degree. $15.2 \%$ of the respondents have master degree while $0.6 \%$ each hold Ph.D. degree and WASC certificate.
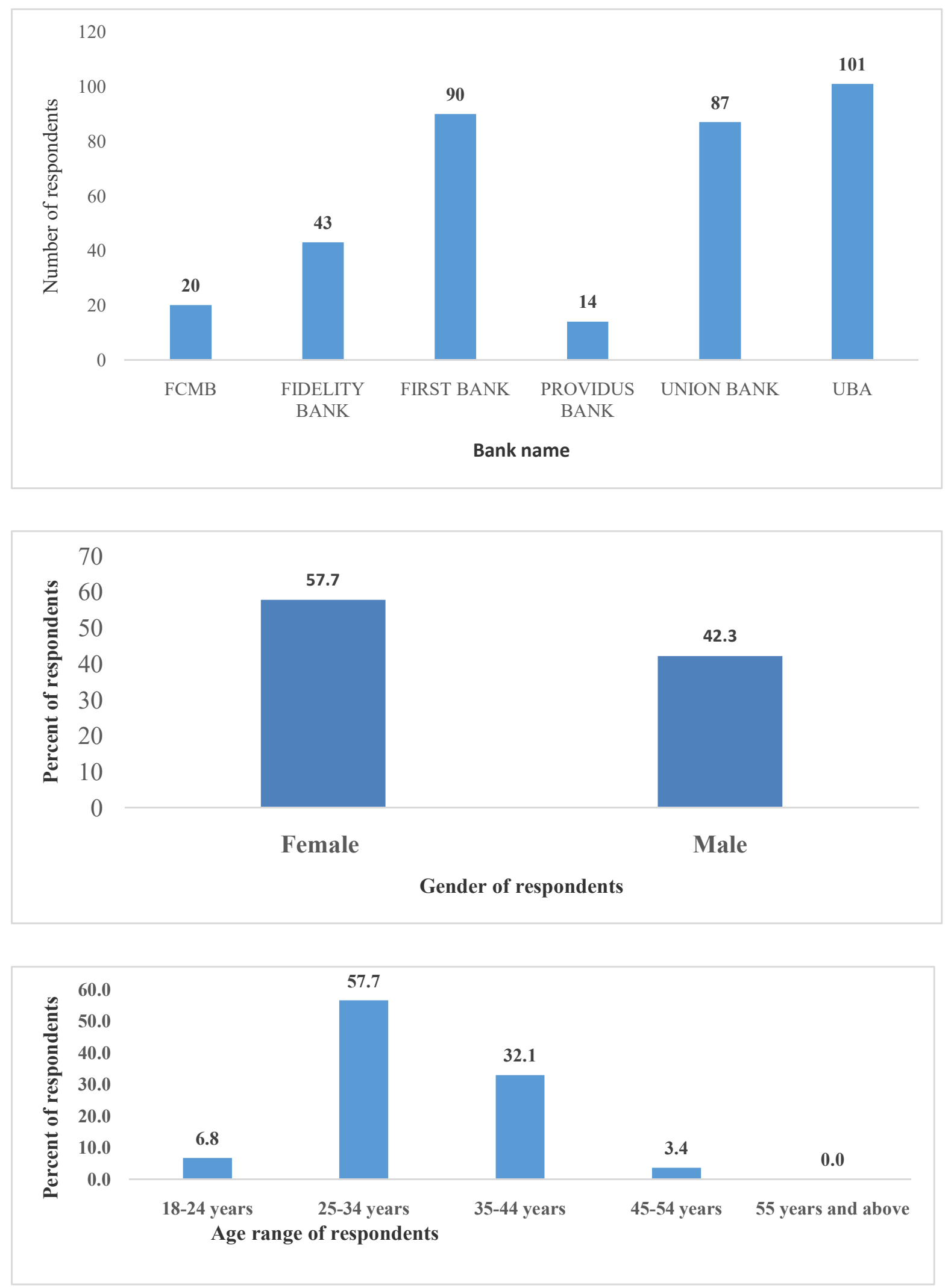


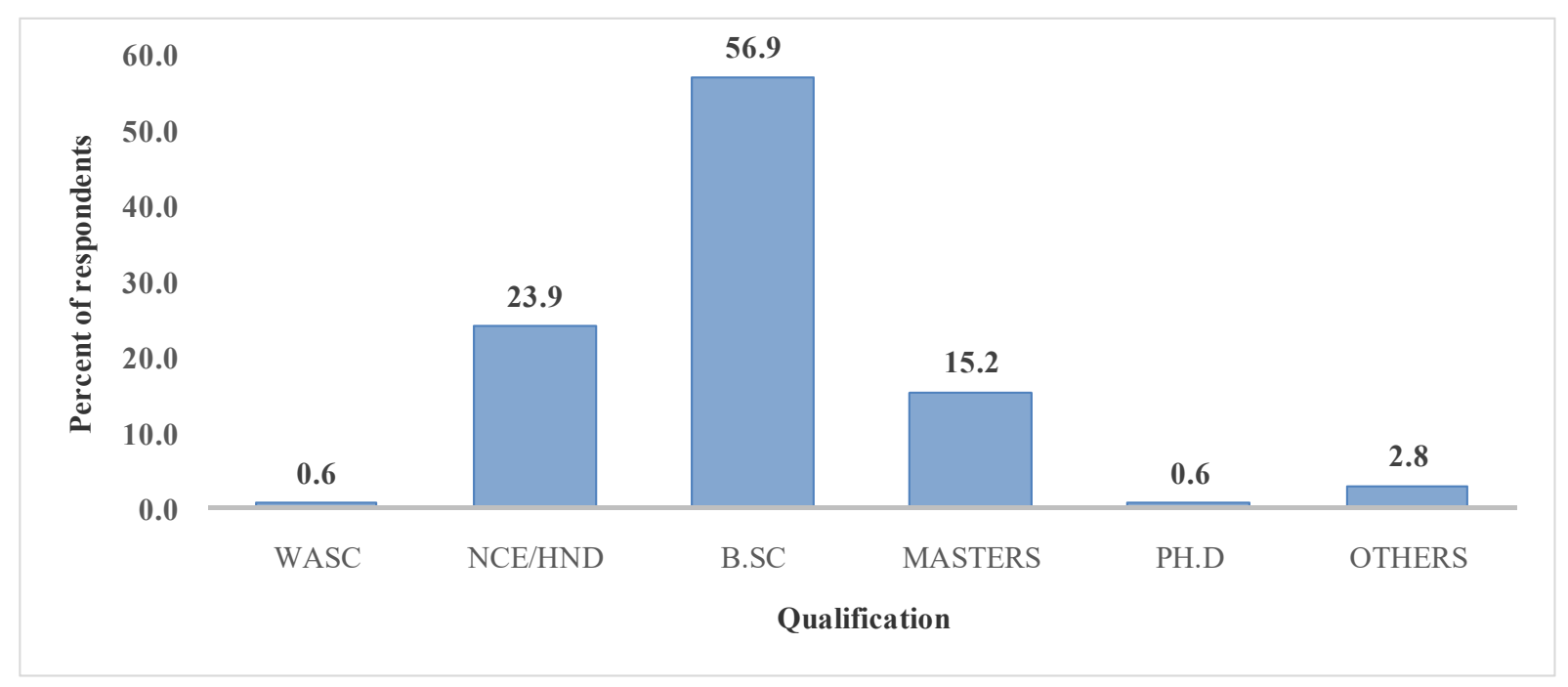

Figure 1: Demographic distribution of Respondents

Table 2 shows the opinions of the respondents on each of the twenty occupational health and safety hazards in the banks to varying proportions from not sure, not at all, some extent, great extent and to very great extent. Common occupational health and safety hazards in the commercial banks include stress $(75.21 \%, \mathrm{n}=267)$, workload $(67.34 \%, \mathrm{n}=238)$, eye strain $(56.34 \%, \mathrm{n}=200) .41 .12 \%$ of the respondents, corresponding to 146 respondents have slipped at one time or the other while $58.88 \%$ of the respondents have not. However, majority of the respondents $(80.57 \%, n=286)$ have not witnessed workplace violence. The respondents agreed that less common occupational health and safety hazards in the banks include poor body posture $(74.37 \%, n=267)$, poor ventilation $(77.47 \%, \mathrm{n}=275)$, poor housekeeping $(74.65 \%$, $\mathrm{n}=265)$, victimization $(70.99 \%, \mathrm{n}=252)$ and sexual harassment $(82.82 \%, \mathrm{n}=297)$.

Table 3 shows the ranking of occupational health and safety hazards the bank workers suffer from while working for commercial banks. The top most common hazards the workers encounter are stress with criterion mean of 3.1803, workload with criterion mean of 2.9746 , eyes strain with criterion mean of 2.6845 , noise with criterion mean of 2.6366 and ergonomic strain with criterion mean of 2. 4423. The least common occupational health and safety hazards the bankers experience are poor body posture (criterion mean - 2.2310), poor ventilation (criterion mean - 2.2697), poor housekeeping (criterion mean-2.2169), sexual harassment (criterion mean-2.1437), and workplace violence (criterion mean-2.1296).

Table 4 shows the top most commonly employed methods and tools for managing occupational health and safety hazards and risks which are as follows: pre-employment screening (3.7332), awareness and sensitization of staff (3.7070), annual medical examination (3.6894), involvement of workers in identifying work related

hazards and risks, and corresponding controls (3.6282) and identification of hazards (3.6169). However, the least common approaches are the use of tips and videos on health and safety (3.2698), audit (3.2113), publication and communication of occupational health and safety policy (3.1831), administration of occupational health and safety assessment checklist (3.0282) and appointment of Incident/HSE Manager (2.9239). 
Table 2: Data collected on Occupational Health and Safety Hazards in the Banks

\begin{tabular}{|c|c|c|c|c|c|c|}
\hline $\mathrm{SN}$ & Occupational Health and Safety Hazards & $\begin{array}{c}\text { Not Sure } \\
\text { (1) }\end{array}$ & $\begin{array}{c}\text { Not at All } \\
\text { (2) }\end{array}$ & $\begin{array}{c}\text { Some Extent } \\
\text { (3) }\end{array}$ & $\begin{array}{c}\text { Great Extent } \\
\text { (4) }\end{array}$ & $\begin{array}{c}\text { Very Great } \\
\text { Extent } \\
(5)\end{array}$ \\
\hline \multirow{2}{*}{1} & \multirow{2}{*}{ Slips } & 55 & 154 & 119 & 20 & 7 \\
\hline & & $15.49 \%$ & $43.38 \%$ & $33.52 \%$ & $5.63 \%$ & $1.97 \%$ \\
\hline \multirow{2}{*}{2} & \multirow{2}{*}{ Workplace Violence } & 57 & 229 & 44 & 16 & 9 \\
\hline & & $16.06 \%$ & $64.51 \%$ & $12.39 \%$ & $4.51 \%$ & $2.54 \%$ \\
\hline \multirow{2}{*}{3} & \multirow{2}{*}{ Falls } & 46 & 192 & 90 & 23 & 4 \\
\hline & & $12.96 \%$ & $54.08 \%$ & $25.35 \%$ & $6.48 \%$ & $1.13 \%$ \\
\hline \multirow{2}{*}{4} & \multirow{2}{*}{ Trips } & 48 & 156 & 135 & 12 & 4 \\
\hline & & $13.52 \%$ & $43.94 \%$ & $38.03 \%$ & $3.38 \%$ & $1.13 \%$ \\
\hline \multirow[b]{2}{*}{5} & \multirow{2}{*}{ Noise } & 32 & 127 & 143 & 44 & 9 \\
\hline & & $9.01 \%$ & $35.77 \%$ & $40.28 \%$ & $12.39 \%$ & $2.54 \%$ \\
\hline \multirow{2}{*}{6} & \multirow{2}{*}{ Poor Lighting } & 41 & 177 & 103 & 29 & 5 \\
\hline & & $11.55 \%$ & $49.86 \%$ & $29.01 \%$ & $8.17 \%$ & $1.41 \%$ \\
\hline \multirow{2}{*}{7} & \multirow{2}{*}{ Ergonomic Strains } & 49 & 154 & 108 & 34 & 10 \\
\hline & & $13.80 \%$ & $43.38 \%$ & $30.42 \%$ & $9.58 \%$ & $2.82 \%$ \\
\hline \multirow{2}{*}{8} & \multirow{2}{*}{ Eye Strains } & 37 & 118 & 131 & 58 & 11 \\
\hline & & $10.42 \%$ & $33.24 \%$ & $36.90 \%$ & $16.34 \%$ & $3.10 \%$ \\
\hline \multirow{2}{*}{9} & \multirow{2}{*}{ Poor work station } & 32 & 195 & 87 & 30 & 11 \\
\hline & & $9.01 \%$ & $54.93 \%$ & $24.51 \%$ & $8.45 \%$ & $3.10 \%$ \\
\hline \multirow{2}{*}{10} & \multirow{2}{*}{ Poor indoor air quality } & 44 & 190 & 84 & 25 & 12 \\
\hline & & $12.39 \%$ & $53.52 \%$ & $23.66 \%$ & $7.04 \%$ & $3.38 \%$ \\
\hline \multirow{2}{*}{11} & \multirow{2}{*}{ Workload } & 26 & 91 & 138 & 66 & 34 \\
\hline & & $7.32 \%$ & $25.63 \%$ & $38.87 \%$ & $18.59 \%$ & $9.58 \%$ \\
\hline \multirow{2}{*}{12} & \multirow{2}{*}{ Dust } & 52 & 189 & 63 & 44 & 7 \\
\hline & & $14.65 \%$ & $53.24 \%$ & $17.75 \%$ & $12.39 \%$ & $1.97 \%$ \\
\hline \multirow{2}{*}{13} & & 46 & 196 & 74 & 30 & 9 \\
\hline & Chemical-Detergent/Cleaning Solution & $12.96 \%$ & $55.21 \%$ & $20.85 \%$ & $8.45 \%$ & $2.54 \%$ \\
\hline & & 47 & 218 & 63 & 20 & 7 \\
\hline 14 & Poor house keeping & $13.24 \%$ & $61.41 \%$ & $17.75 \%$ & $5.63 \%$ & $1.97 \%$ \\
\hline 15 & Dore Vontibation & 41 & 234 & 48 & 25 & 7 \\
\hline 15 & Poor Ventilation & $11.55 \%$ & $65.92 \%$ & $13.52 \%$ & $7.04 \%$ & $1.97 \%$ \\
\hline & & 51 & 182 & 86 & 24 & 12 \\
\hline 16 & Electric Shock & $14.37 \%$ & $51.27 \%$ & $24.23 \%$ & $6.76 \%$ & $3.38 \%$ \\
\hline & & 47 & 217 & 63 & 18 & 10 \\
\hline 17 & Poor Body Posture & $13.24 \%$ & $61.13 \%$ & $17.75 \%$ & $5.07 \%$ & $2.82 \%$ \\
\hline & & 46 & 206 & 52 & 40 & 11 \\
\hline 18 & Victimization & $12.96 \%$ & $58.03 \%$ & $14.65 \%$ & $11.27 \%$ & $3.10 \%$ \\
\hline 10 & S & 53 & 241 & 27 & 25 & 9 \\
\hline 19 & Sexual Harrassment & $14.93 \%$ & $67.89 \%$ & $7.61 \%$ & $7.04 \%$ & $2.54 \%$ \\
\hline & & 16 & 72 & 143 & 80 & 44 \\
\hline 20 & Stress & $4.51 \%$ & $20.28 \%$ & $40.28 \%$ & $22.54 \%$ & $12.39 \%$ \\
\hline
\end{tabular}


Occupational Health and Safety Hazards and Risks in Nigerian Commercial Banks

Table 3: Perception of Bank Workers on Occupational Health and Safety Hazards

\begin{tabular}{|c|c|c|c|c|c|}
\hline Occupational Health and Safety Hazards & $\mathrm{N}$ & Minimum & Maximum & $\begin{array}{c}\text { Criterion } \\
\text { Mean }\end{array}$ & $\begin{array}{l}\text { Standard } \\
\text { Deviation }\end{array}$ \\
\hline Stress & 355 & 1 & 5 & 3.1803 & 1.0352 \\
\hline Workload & 355 & 1 & 5 & 2.9746 & 1.0572 \\
\hline Eye Strains & 355 & 1 & 5 & 2.6845 & 0.9680 \\
\hline Noise & 355 & 1 & 5 & 2.6366 & 0.9009 \\
\hline Ergonomic Strains & 355 & 1 & 5 & 2.4423 & 0.9398 \\
\hline Poor work station & 355 & 1 & 5 & 2.4169 & 0.8822 \\
\hline Poor Lighting & 355 & 1 & 5 & 2.3803 & 0.8453 \\
\hline Poor indoor air quality & 355 & 1 & 5 & 2.3549 & 0.9058 \\
\hline Slips & 355 & 1 & 5 & 2.3521 & 0.8769 \\
\hline Trips & 355 & 1 & 5 & 2.3465 & 0.7950 \\
\hline Dust & 355 & 1 & 5 & 2.3380 & 0.9396 \\
\hline Electric Shock & 355 & 1 & 5 & 2.3352 & 0.9210 \\
\hline Victimization & 355 & 1 & 5 & 2.3352 & 0.9451 \\
\hline Chemical-Detergent/Cleaning Solution & 355 & 1 & 5 & 2.3239 & 0.8940 \\
\hline Falls & 355 & 1 & 5 & 2.2873 & 0.8131 \\
\hline Poor Body Posture & 355 & 1 & 5 & 2.2310 & 0.8443 \\
\hline Poor Ventilation & 355 & 1 & 5 & 2.2197 & 0.8134 \\
\hline Poor house keeping & 355 & 1 & 5 & 2.2169 & 0.8159 \\
\hline Sexual Harrassment & 355 & 1 & 5 & 2.1437 & 0.8453 \\
\hline Workplace Violence & 355 & 1 & 5 & 2.1296 & 0.8223 \\
\hline
\end{tabular}

Table 4: Perception on Management of Occupational Health and Safety Hazards and risks

\begin{tabular}{|c|c|c|c|c|c|}
\hline How Banks manage Occupational Health and Safety Hazards and Risks & $\mathrm{N}$ & Minimum & Maximum & $\begin{array}{l}\text { Criterion } \\
\text { Mean }\end{array}$ & $\begin{array}{l}\text { Std. } \\
\text { Deviation }\end{array}$ \\
\hline Pre-employment screening & 355 & 1 & 5 & 3.7324 & 1.1623 \\
\hline Awareness and sensitization of staff & 355 & 1 & 5 & 3.7070 & 1.0609 \\
\hline Annual Medical Examination of staff & 355 & 1 & 5 & 3.6394 & 1.1529 \\
\hline $\begin{array}{l}\text { Involvement of workers in identifying work hazards and risk, and } \\
\text { corresponding controls }\end{array}$ & 355 & 1 & 5 & 3.6282 & 1.0194 \\
\hline Hazard Identification & 355 & 1 & 5 & 3.6169 & 1.0399 \\
\hline Regular communication to workers & 355 & 1 & 5 & 3.5859 & 1.0853 \\
\hline Training for staff on safe practices & 355 & 1 & 5 & 3.5859 & 1.1335 \\
\hline Top Management attitude and disposition & 355 & 1 & 5 & 3.4282 & 1.1245 \\
\hline Use of HSE tips and videos & 355 & 1 & 5 & 3.2648 & 1.2092 \\
\hline Conduct audit periodically on all locations and works & 355 & 1 & 5 & 3.2113 & 1.2550 \\
\hline Elaboration and issuance of $\mathrm{OH} \& \mathrm{~S}$ policy to employees & 355 & 1 & 5 & 3.1831 & 1.1569 \\
\hline Administration of $\mathrm{OH} \& \mathrm{~S}$ Assessment checklist & 355 & 1 & 5 & 3.0282 & 1.1673 \\
\hline Appointment of Incident Manager/HSE Manager & 355 & 1 & 5 & 2.9239 & 1.2160 \\
\hline
\end{tabular}




\section{DISCUSSION}

The study revealed that $75.25 \%$ of the respondents who are workers of the six commercial banks surveyed suffered from stress, a type of hazard in the workplace. This is similar to the findings of [15], [16],[8] who argued that stress was a daily experience of bank workers. This further support the findings presented in Table 3 which showed that stress has the highest criterion mean of 3.18 out of all other occupational health and safety hazards the respondents provided their perceptions on. The perceptions of the bank workers on the occupational health and safety hazards also showed that they are exposed marginally to some other forms of hazards as revealed in Table 2 to great extent. The extent to which the respondents experienced the occupational health and safety hazards in the banks varied as follows: $67.04 \%$ of the bank workers are exposed to workload; $56.34 \%$ of the respondents suffer eye strains.

Furthermore, 55.21\% of the respondents experienced noise, $42.82 \%$ of the respondents suffered ergonomic strains which appeared to be lower in the study carried out by [17]. Other occupational health and safety hazards which the bank workers are exposed to at lower levels are poor body posture, sexual harassment, workplace violence, falls, slips, trips, poor ventilation, poor work stations, victimisation and dust. Table 3 shows the hazards and criterion mean of the hazards based on the perception of the respondents. The Occupational Health and Safety (OHS) hazard with most criterion mean was stress (3.1803), followed by workload (2.9746), and next, eye strain (2.6845), and following eye strain was noise (2.6366) and after noise, was ergonomics strain with criterion mean of 2.44. The results also threw up other OHS hazards affecting the productivity and quality of work of the bank workers. They are falls (2.2310), trips (2.3465), slips (2.3521). The least hazard the bank workers are faced based upon the perception provided was workplace violence with criterion mean of 2.1296 , followed by sexual harassment with criterion mean of 2.1437 .

With the above findings, the organizations are thus offered the opportunity to address identified and critical areas of vulnerability and rightly design appropriate programs to improve health and safety of the employees. Results of the study showed that stress, workload and eye strain were the major hazards experienced by Nigerian commercial bank workers. The implication is that these hazards would affect productivity to an extent, mar performance and create bodily pains as advanced in the work of [12], [16].

The results of the study presented in Table 4 showed that many methods and approaches are used to manage occupational health and safety hazards common to the bank workers working in the six commercial banks surveyed based on the perceptions of these workers. The summary of perceptions of bank workers on the question asked on management of occupational health and safety hazards in their banks suggested the following: pre-employment screening with criterion mean of 3.7324 appeared to be seen as crucial in addressing occupational health and safety hazards. The responses of the respondents also showed that awareness, education and sensitization are highly important and should be engaged as a method that could help eliminate occupational health and safety hazards in the banks. This align with the view of [18] which suggests that safety education is the only available method of creating positive attitudinal changes of stakeholders of an organization and concluded that education significantly correlated with safety awareness among workers of an organization.

The criterion means of 3.7070 for awareness and sensitization was the second highest in the perceptions rating of the bank workers of the six commercial banks. Other perceptions held by the bank workers on the question of occupational health and safety hazards management include: annual medical examination of staff with criterion mean of 3.6344 , involvement of workers in identifying controls (3.6282), hazard identification (3.6169), regular communication to workers (3.5859), top management commitment and disposition which has criterion mean of 3.4252 which further agrees with result of the hypothesis which showed that there was a strong correlation between top management commitment and walking the talks with the ability of the organization to eliminate hazards and minimize risk.

\section{CONCLUSION}

The study concluded that stress had the highest criterion mean of 3.1803 and 2.1296 was the least criterion mean attributed to workplace violence. Furthermore, the perceptions of bank workers have revealed that banks address their occupational health and safety hazards and risks with a form of standard prescription based on ISO 45001 occupational health and safety management system standard. This implies that the banks have structured processes that identify hazards, assess the hazards and control the risk.

\section{Conflict of Interest}

The author(s) declare no potential conflict of interest with respect to the research, authorship, and/or publication of this article.

\section{REFERENCES}

[1] K. Pearson. The causes and incidence of occupational accidents and ill-health across the globe. British Safety Council,2009.

[2] O.Kalatpour\& S. Khavaji, Occupational injuries overview: general descriptive study of the petrochemical construction industries. Caspian journal of health research, 2(1), 2016, 37-43.

[3] B. S.Roudsari, \& M. Ghodsi. Occupational injuries in Tehran. Injury, 36(1), 2005, 33-39.

[4] C. M. Tam, S. X. Zeng,\&Z. M. Deng. Identifying elements of poor construction safety management in China. Safety science, 42(7), 2004, 569-586.

[5] ILO. Promotional Framework for Occupational Safety and Health. Geneva. 2005.

[6] S. Gök. Prevalence and types of mobbing behavior: A research on banking employees. Journal of Human Sciences, 8(1), 2011, 318-334.

[7] L. Rosenstock,M. Cullen,\&M. Fingerhut. Occupational health. Disease Control Priorities in Developing Countries. 2006. 2nd edition.

[8] I. F. Eberendu,G. C. Agu, D. E. Ihekaire, J. E. Obioma, S. J. Ozims,C.C. Obasi,H. U. Nwanjo, H. C. Amah,D. C. Nwosu,C. C. Amah,U. Uchegbu,E. I. Obeagu, \&I. E. Ibanga. Workplace Health Risk Associated Diseases and the Practice of Workplace Health Promotion in Nigerian Banking Sector. J Biomed Sci Appl, 2(1), 2018, 1.

[9] A. A. Adenugba,\& C. O. Ilupeju. Working Conditions of Female Marketers in Selected New Generation Bankks in Ibadan, 
Nigeria. Journal of Research in National Development, 10(2), 2012, 199-207.

[10] C. O. Akenbor,\& S. Imade. Sales target and ethical behaviour of marketing executives in the Nigerian banking industry. African Research Review, 5(3).2011.

[11] A. Desa,N. Habidin, S. Hibadullah,N. Fuzi,\&F. Zamri. OHSAS 18001 Performance Efforts and OSHA Performance in Malaysian Automotive Industry. Journal of Environmental Science, Computer Science, Engineering and Technology. 2(2). 2013, 217-227

[12] S. Ajayi. Effect of Stress on Employee Performance and Job Satisfaction: A Case Study of Nigerian Banking Industry. 2018.

[13] D. Girisa,E. Gatabe,\&P. Njogu. Current occupational safety and health practices within selected banks in Nakuru County,Kenya. International Journal of Advanced Research. 6(8), 2018, 845-857.

[14] I. Mohammadfam, M. Kalalinia,M. Momeni,R. Golmohammadi,Y. Hamidi,\&A. Soltanian. Developing an integrated decision making approach to assess andpromote the effectiveness of occupational health and safety management systems. Journal of Cleaner Production. 127, 2016, 119-131.

[15] B. Essien. Occupational stress and coping strategies among female employees of Commercial Banks in Nigeria. International Journal of Scientific Research and Management.2 (9). 2014,1917-1930.

[16] U. Undie, S. Ukpata, \&S. Iyortsuun. Job stress and employee performance in Nigerian Banking Sector. International Journal of Modern Management Sciences. 7(8), 2018, 40-51

[17] M. Maduagwu, R. Maijindadi, K. Duniya, A. Oyeyemi,I. Saidu, \&B Aremu. Prevalence and Patterns of Work-related Musculoskeletal Disorders among Bankers in Maiduguri, Northeast Nigeria. Occupational Medicine and Health Affairs. 2(3). 2014

[18] S. Gyekye, \&S. Salminen. Organizational safety climate and work experience. International Journal of Occupational Safety and Ergonomics, 16(4), 2010, 431-443. 